Article

\title{
Responses of Cynanchum taiwanianum and Its Bioactive Compound Biosynthesis to Levels of Nitrogen and Potassium Fertilization
}

\author{
Han-Mei Tseng ${ }^{1}$, Tzy-Ming $\mathrm{Lu}^{2}$ and Lean-Teik $\mathrm{Ng}^{2, *}$ \\ 1 Department of Agricultural Chemistry, National Taiwan University, No. 1, Sec. 4, Roosevelt Road, \\ Taipei 10617, Taiwan; r04623020@ntu.edu.tw \\ 2 Department of Pharmacy, Tajen University, No. 20, Weixin Road, Yanpu, Pingtung 90741, Taiwan; \\ cmlu@mail.tajen.edu.tw \\ * Correspondence: nglt97@ntu.edu.tw
}

check for updates

Citation: Tseng, H.-M.; Lu, T.-M.; $\mathrm{Ng}$, L.-T. Responses of Cynanchum taiwanianum and Its Bioactive

Compound Biosynthesis to Levels of Nitrogen and Potassium Fertilization Agronomy 2022, 12, 180. https:// doi.org/10.3390/agronomy12010180

Academic Editor: Leo Sabatino

Received: 10 December 2021

Accepted: 7 January 2022

Published: 12 January 2022

Publisher's Note: MDPI stays neutral with regard to jurisdictional claims in published maps and institutional affiliations.

Copyright: (C) 2022 by the authors. Licensee MDPI, Basel, Switzerland. This article is an open access article distributed under the terms and conditions of the Creative Commons Attribution (CC BY) license (https:// creativecommons.org/licenses/by/ $4.0 /)$.

\begin{abstract}
Cynanchum taiwanianum is an important plant used in traditional medicine. The increasing demand and lack of information regarding its cultivation have become concerns for sustainability. This study examined the effects of nitrogen and potassium fertilization rates on the growth and biosynthesis of main bioactive compounds, including cynandione A and polyphenolic compounds, in field-cultivated C. taiwanianum. Two field experiments were conducted using three levels of nitrogen (N100, N150 and N200) and three levels of potassium (K100, K150 and K200) treatments. The experimental variables were either $\mathrm{N}$ or $\mathrm{K}$ fertilizer. The results showed that, aside from N200, N and $\mathrm{K}$ fertilization significantly increased $\mathrm{C}$. taiwanianum shoot and tuber biomass. High $\mathrm{N}$ fertilization resulted in low total phenolic and total flavonoid contents in shoots and tubers, but the effects of $\mathrm{K}$ fertilization were minimal. Cynandione $\mathrm{A}$, an important bioactive compound, was only detected in tubers; its content were enhanced with the increasing $\mathrm{K}$ fertilization, but reduced with excess $\mathrm{N}$ fertilization (N200). Although N and K fertilizers are important for C. taiwanianum tuber production, the yield of cynandione $\mathrm{A}$ was associated with $\mathrm{K}$ but not $\mathrm{N}$ fertilization rates. These results provide some essential information for the optimal production of $C$. taiwanianum tubers and functional compounds. Further studies are required to examine the mechanism(s) of cynandione A biosynthesis and its compartmentation in plant tissues.
\end{abstract}

Keywords: Cynanchum taiwanianum; fertilization rates; tuber yield; cynandione A; bioactive compounds

\section{Introduction}

Cynanchum taiwanianum Yamazaki (Asclepiadaceae), also known as Bo-Ye-Niu-Pi-Xiao or Wang-Ling-Shu, is an important medicinal plant in Taiwan. Aside from being traditionally used for treating snake bites, stomach ulcers, liver disease, hypercholesterolemia and constipation [1], its tubers are also consumed as tonic foods. Pharmacological studies have shown that tubers of C. taiwanianum possess anti-inflammatory [2], antioxidant [2], anticancer [3,4] and antiplatelet aggregation [5] activities. It was shown to contain cynandiones A, B, C and D, cynanchone A, germanicol acetate, cycloartenol [3], cynantetrone [4], 2,5 -dihydroxyacetophenone [6], $\beta$-amyrin, sitosteryl-3-O- $\beta$-D-glucopyranoside, cynanonesides A and B [7], 3,4-dihydroxyacetophenone, 4-hydroxyacetophe-none [8], and taiwanosides A, B, C, D and E [9]. Cynandione A, a dimeric acetophenone that can be classified as abridged phenylpropanoid, or plant phenolics, is usually metabolized from tyrosine. It is an important bioactive marker of Cynanchum species, and was shown to possess neuroprotective [10,11], anti-inflammatory [11,12], hepatoprotective [13], and hypoglycemic [14] activities, as well as attenuating neuropathic pain [15].

With the increase in the popularity of botanical medicine and the demand of medicinal plant materials, various technological strategies were developed to increase the yield and 
quality of these bioresources. In general, the contents of bioactive ingredients in plants are influenced by genotype, cultivation practices, period of cultivation, stages of growth, environmental conditions and fertilizers applied [16,17]. Both nitrogen $(\mathrm{N})$ and potassium $(\mathrm{K})$ availabilities were reported to influence tuber dry matter of plants [18,19]. Nitrogen is one of the most important macronutrients for plant growth and biomass development [19]. It forms a component of chlorophyll, proteins, nucleic acids, alkaloids and other substances in plants. In addition, nitrogen may also affect the activity of phenylalanine ammonia lyase in the secondary metabolic pathway, and thus affect the secondary metabolite content in plants $[20,21]$. Potassium plays an important role in controlling plant enzyme activity, cation-anion homeostasis and membrane polarization, as well as protein and starch synthesis, and crop quality $[19,20]$. For tuberous plants, K promotes the conversion and transport of sugars, allowing photosynthetic products to be rapidly transported to tubers (roots), and thus promoting tuber growth [22].

Studies showed that increased $\mathrm{K}$ application can increase total phenolic and total flavonoid contents in sweet potato and basil leaves [23,24]. Under severe K deficiency, $\mathrm{N}$ fertilization can enhance alkaloid concentrations in Lupinus angustifolius [25]. Excessive $\mathrm{N}$ fertilizer application was reported to reduce polyphenol contents in fruits and vegetables [26,27], and phenolic compound bioavailability in wheat grains [28].

Our preliminary studies showed that, under the conditions of organic fertilization, an amount of $150 \mathrm{~kg}$ of $\mathrm{N} \mathrm{ha}^{-1}$ produced the best quality C. taiwanianum tubers and had the highest content of cynandione A (unpublished data). In this study, we hypothesized that $\mathrm{N}$ and $\mathrm{K}$ application may affect the tuber biomass of $\mathrm{C}$. taiwanianum and its bioactive compound biosynthesis. Therefore, the effects of $\mathrm{N}$ and $\mathrm{K}$ fertilization rates on the growth and biosynthesis of main bioactive compounds, including cynandione A and polyphenolic compounds, were examined in field-cultivated C. taiwanianum. In the repeated field experiments, $C$. taiwanianum seedlings were subjected to different levels of $\mathrm{N}$ or $\mathrm{K}$ fertilization for a period of 180 days, followed by an examination of the yield and the production of cynandione A, total phenols, total flavonoids and selected polyphenolic compounds, with the goal of achieving the maximum yields of both $C$. taiwanianum tubers and the targeted bioactive components.

\section{Materials and Methods}

\subsection{Chemicals}

Polyphenolic standards such as gallic acid, p-hydroxybenzoic acid, catechin, chlorogenic acid, vanillic acid, caffeic acid, epicatechin, p-coumaric acid, ferulic acid, ellagic acid, cinnamic acid and quercetin, with purity greater than $95 \%$, were purchased from Sigma Chemical Co. (St. Louis, MO, USA). Cynandione A was isolated from tubers of C. taiwanianum, as reported previously [3], and its purity was $>99 \%$. All other chemicals used were of analytical grade.

\subsection{Plant Materials and Experimental Conditions}

Cynanchum taiwanianum Yamazaki seedlings were obtained by vegetative propagation, and they were used for experiments after reaching the height of $5 \mathrm{~cm}$ with 5-6 leaves.

The chemical fertilizers used were urea ( $\mathrm{N}$ content $46 \%)$, potassium sulfate $\left(\mathrm{K}_{2} \mathrm{O}\right.$ content $50 \%)$ and superphosphate $\left(\mathrm{P}_{2} \mathrm{O}_{5}\right.$ content $\left.12 \%\right)$. During the experimental period, no pesticides were applied, and the climatic data (i.e., temperature and precipitation) collected are presented in Supplementary Materials (Figures S1 and S2). To maintain soil moisture at the approximate field capacity, tap water was used to water the plants throughout the experimental period.

\subsection{Experimental Designs}

The field experiment was conducted at the experimental farm of National Taiwan University from 3 October 2016 to 31 March 2017, a period of approximately 180 days. To test the hypothesis that fertilization with $150 \mathrm{~kg}$ of $\mathrm{N} \mathrm{ha}^{-1}$ improves $C$. taiwanianum 
production and quality, two experiments were conducted with different application rates of $\mathrm{N}$ and $\mathrm{K}$ fertilizer treatments, with four replicates for each treatment. The size of the experimental plot was $15 \mathrm{~m} \times 9 \mathrm{~m}$, consisting of four rows with a row spacing of $2 \mathrm{~m}$ and a plant spacing of $2.5 \mathrm{~m}$. The test was a single-factor treatment. The experimental variables were either the $\mathrm{N}$ or $\mathrm{K}$ fertilizer at different rates. For $\mathrm{N}$ treatment groups, there were three different rates of $\mathrm{N}$ fertilizer: $100 \mathrm{~kg} \mathrm{~N}^{-1}$ (N100), $150 \mathrm{~kg} \mathrm{~N}^{-1}$ (N150) and $200 \mathrm{~kg}$ $\mathrm{N} \mathrm{ha}^{-1}$ (N200), and these treatment groups received the same amount of $\mathrm{K}\left(150 \mathrm{~kg} \mathrm{~K}_{2} \mathrm{O}\right.$ $\left.\mathrm{ha}^{-1}\right)$ and $\mathrm{P}\left(90 \mathrm{~kg} \mathrm{P}_{2} \mathrm{O}_{5} \mathrm{ha}^{-1}\right)$ fertilizers. For $\mathrm{K}$ treatment groups, there were three levels of K treatment: $\mathrm{K} 100\left(100 \mathrm{~kg} \mathrm{~K}_{2} \mathrm{O} \mathrm{ha}^{-1}\right), \mathrm{K} 150\left(150 \mathrm{~kg} \mathrm{~K}_{2} \mathrm{O} \mathrm{ha}^{-1}\right)$ and $\mathrm{K} 200\left(200 \mathrm{~kg} \mathrm{~K}_{2} \mathrm{O}\right.$ $\left.\mathrm{ha}^{-1}\right)$; each of these treatment groups received the same amount of $\mathrm{N}\left(150 \mathrm{~kg} \mathrm{~N} \mathrm{ha}^{-1}\right)$ and $\mathrm{P}\left(90 \mathrm{~kg} \mathrm{P}_{2} \mathrm{O}_{5} \mathrm{ha}^{-1}\right.$ ) fertilizers (Table S1). Fertilizers were applied in the form of basal fertilizer and top dressing; basal fertilizers containing N, P and K nutrients were well mixed and incorporated into the soil at sowing; the first top dressing application time was on 6 December 2016 (two months after planting), the second top dressing application time was on 3 February 2017 (four months after planting). The control group in both $\mathrm{N}$ and $\mathrm{K}$ treatments received no fertilization. All fertilizers were applied in a subsurface ring about $5 \mathrm{~cm}$ from plants.

\subsection{Soil Chemical Analysis}

Soil samples were taken before planting and after harvesting, which formed the basis for the environmental chemical properties of the study. The sampling depth was limited to $30 \mathrm{~cm}$ and about $15 \mathrm{~cm}$ around each plant; the soil was collected from ten points randomly, and mixed into one sample. After air-drying, the soil samples were pulverized and passed through a $2 \mathrm{~mm}$ sieve, and then subjected to the analysis of $\mathrm{pH}$, electric conductivity (EC), total N, Mehlich III extractable P and K, and organic matter. Soil $\mathrm{pH}$ (1:1 soil:water) and EC of the saturation extract were determined according to McLean [29] and Rhoades [30], respectively. Soil extractable P and K was measured by the molybdenum-blue method [31] and flame photometer (Model 410C, Sherwood Scientific Ltd., Cambridge, UK), respectively, following Mehlich III extraction [32]. Soil total N and organic matter were measured by the Kjeldahl digestion-distillation method [33] and dichromate-oxidation method [34], respectively.

\subsection{Plant Sample Processing}

At the end of the experiment, whole plants of all treatments were harvested, and then cleaned with deionized water. They were then separated into shoots (stem and leaf) and tubers (roots), followed by measuring the fresh weight. After drying at $60{ }^{\circ} \mathrm{C}$ to a constant weight, the dry matter yield of samples was determined. The dried materials were ground to pass a 40-mesh sieve to obtain the powdered samples, which were collected in an air-tight plastic bag and stored in a desiccator until analysis. Total N, P and K contents were determined by Kjeldahl digestion-distillation method, molybdenum-blue method and flame photometry, respectively, after digestion of the plant material with a mixture of salicylic acid, sulfuric acid and sodium thiosulfate [33].

\subsection{Analysis of Total Flavonoid and Total Phenolic Contents}

The total flavonoid and total phenolic contents in samples were determined by the colorimetric and Folin-Ciocalteu methods, respectively, as described previously [35]. The total flavonoid content was expressed as grams quercetin equivalent per $\mathrm{kg}$ dry weight of sample, whereas the total phenolic content was expressed as grams gallic acid equivalent per kg dry weight of sample.

\subsection{Chromatographic Analysis of Polyphenolic Constituents}

The analysis of polyphenolic constituents in samples was performed according to procedures described previously [36], using a Hitachi high-performance liquid chromatographic (HPLC) system equipped with a pump (Model L-2130) and a UV/Vis Detector 
(Model L-2420), set at wavelength $280 \mathrm{~nm}$. The separation was performed on an octadecyl column (Mightysil RP-C18; $5 \mu \mathrm{m}, 4.6 \mathrm{~mm} \times 250 \mathrm{~mm}$ ) at room temperature. The analysis was carried out with $20 \mu \mathrm{L}$ of sample injected into the column coupled with a gradient mobile phase consisting of solvent (A) $2 \%$ aqueous acetic acid and solvent (B) $100 \%$ methanol. The flow rate was set at $1.0 \mathrm{~mL} \mathrm{~min}{ }^{-1}$. The chromatographic gradient was as follows: 0-55 min solvent B from $0 \%$ to $45 \%$, 55-75 min isocratic solvent B $45 \%$, and $75-85 \mathrm{~min}$ solvent B from $45 \%$ to $0 \%$. Quantification of individual polyphenolic compounds was estimated by external standard calibration curves.

\subsection{Analysis of Cynandione A Content}

The analysis of cyandione A content was conducted according to the method described previously [12]. Briefly, $0.1 \mathrm{~g}$ of C. taiwanianum dried powder was taken and mixed thoroughly with $1 \mathrm{~mL}$ of methanol. The mixture was then heated and extracted in a $70-80{ }^{\circ} \mathrm{C}$ water bath for $4 \mathrm{~h}$, followed by making the volume up to $100 \mathrm{~mL}$ with methanol, and filtering through a $0.45 \mu \mathrm{m}$ filter to obtain the filtrate for cynandione A analysis.

The analysis was performed by reverse phase high performance liquid chromatography (RP-HPLC) consisting of an HPLC pump (Hitachi L-2130, Tokyo, Japan), a UV detector (Hitachi L-2420, Tokyo, Japan) set at a wavelength of $290 \mathrm{~nm}$, and a C18 reverse phase column $(5 \mu \mathrm{m}, 4.6 \times 250 \mathrm{~nm}$, Kanto Chemicals, Tokyo, Japan). The mobile phase was made up of $0.1 \%$ formic acid in water (solvent $\mathrm{A}$ ) and $0.1 \%$ formic acid in acetonitrile (solvent B), which were eluted at a flow rate of $0.6 \mathrm{~mL} \mathrm{~min}^{-1}$. The solvent gradient was 0-15 min solvent B from $30 \%$ to $50 \%$, and $15-20$ min solvent B from $50 \%$ to $100 \%$. A volume of $20 \mu \mathrm{L}$ of sample was used for analysis.

\subsection{Statistical Analysis}

Data are presented as mean \pm standard deviation (SD). Values were evaluated by oneway analysis of variance, and then by Least Significant Difference (LSD) tests. Differences between the means of treatments among groups were considered significant when $p$-value was $<0.05$.

\section{Results}

\subsection{Chemical Properties of Soils}

The results showed that, after $\mathrm{C}$. taiwanianum cultivation, the soil $\mathrm{pH}$ values were significantly lower than the $\mathrm{pH}$ (6.4) before the experiment; however, there was no difference in soil $\mathrm{pH}$ among different application rates of $\mathrm{N}$ or $\mathrm{K}$ fertilizer (Figure 1a). Compared to the EC value $\left(0.4 \mathrm{dS} \mathrm{m}^{-1}\right)$ before the experiment, the control group appears to have a lower soil EC value $\left(0.3 \mathrm{dS} \mathrm{m}^{-1}\right)$, while $\mathrm{N}$ and $\mathrm{K}$ treatments resulted in increasing soil EC values after the experiments (Figure 1b); this indicated that fertilization may contribute to the increasing salt content in the soil.

With the exception of the control group, the difference in soil total $\mathrm{N}$ contents among different application rates of $\mathrm{N}$ or $\mathrm{K}$ fertilizer was not statistically significant (Figure 1c). Mehlich-III-extractable P and K contents before the experiment were $76.7 \mathrm{mg} \mathrm{kg}^{-1}$ and $172.5 \mathrm{mg} \mathrm{kg}^{-1}$, respectively. After the experiment, a decrease in the content of extractable $\mathrm{K}\left(141.1 \mathrm{mg} \mathrm{kg}^{-1}\right)$, but not the extractable $\mathrm{P}$, was noted in the soil of the control group (Figure 1d,e). The fertilizer-treated groups demonstrated significantly higher contents of extractable $\mathrm{P}$ and $\mathrm{K}$ than the control group. There was very little difference in soil organic matter content among different $\mathrm{N}$ or $\mathrm{K}$ application rates, and their content in soils before and after experiments were also not significantly different (Figure 1f). 
a

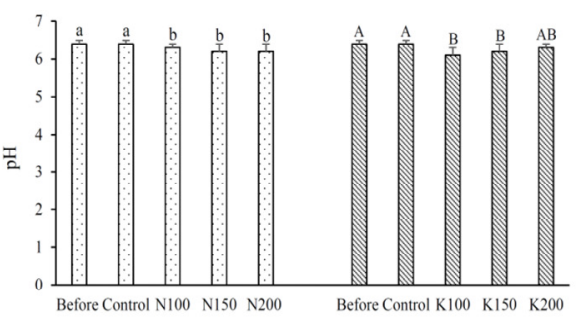

c
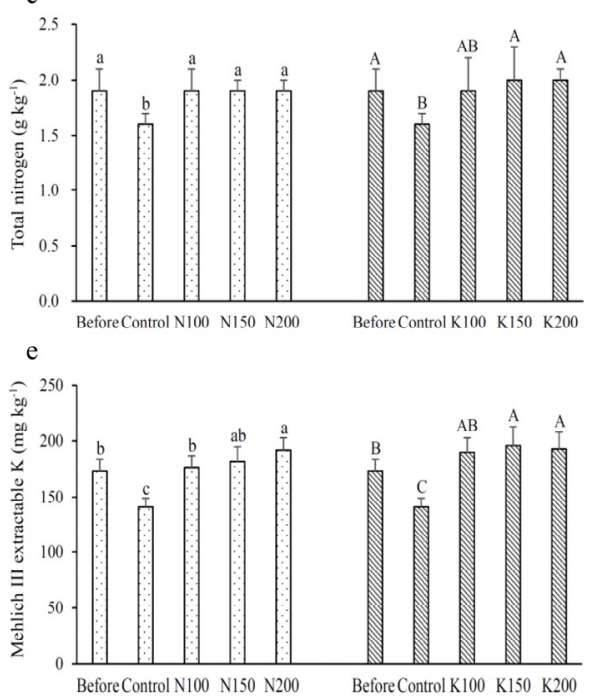

b

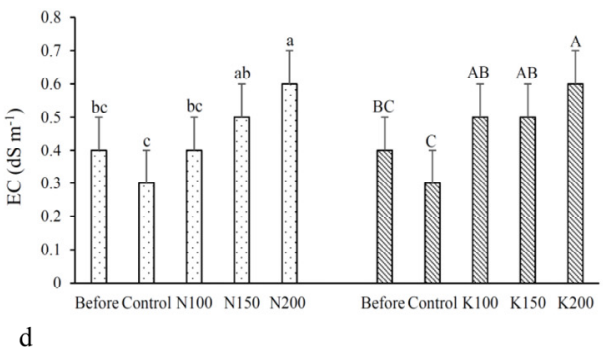

d

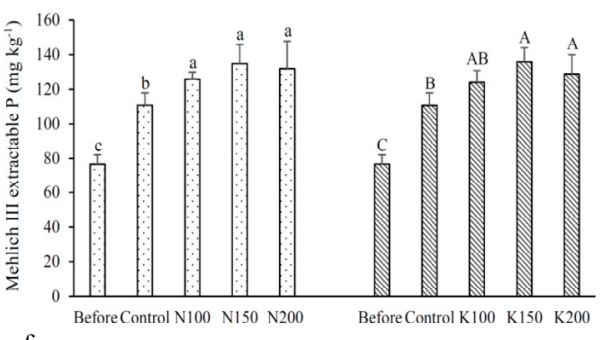

$\mathrm{f}$

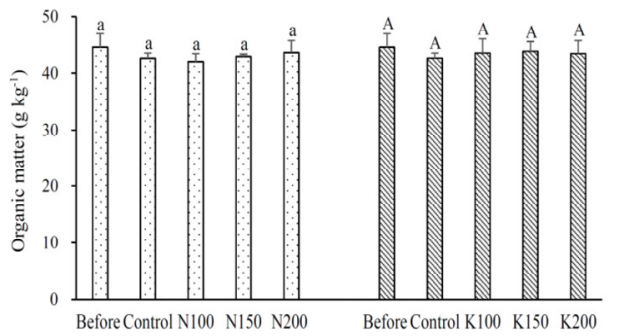

Figure 1. Chemical properties of soil before and after field experiment: (a) pH; (b) EC; (c) Total nitrogen; (d) Mehlich-III-extractable phosphorus; (e) Mehlich-III-extractable potassium; (f) Organic matter. Values are mean \pm standard deviation $(n=4)$. The bars with different letters within the same fertilizer treatment (N treatments: Control, N100, N150 and N200; K treatments: Control, $\mathrm{K} 100, \mathrm{~K} 150$ and K200) are significantly different ( $p<0.05$, LSD tests). EC: Electrical conductivity of saturated extract.

\subsection{Biomass Production}

Figure 2 shows the effects of different fertilizer application rates on the fresh and dry weights of shoots and tubers of C. taiwanianum. The results showed that, aside from N200, increasing $\mathrm{N}$ or $\mathrm{K}$ application rates were able to increase the fresh and dry weights of shoots and tubers. In the N treatments, both N100 and N150 treatments significantly increased the dry weight of tubers by 66-179\%, with N150 treatment having the highest dry weight (215 g plant $^{-1}$ ); however, the fresh and dry weights of tubers in N200 appear to decrease to the level comparable to that of the control group; this indicates that the excessive application of $\mathrm{N}$ fertilizer can inhibit plant growth. Interestingly, the $\mathrm{N} 150$ treatment that had a N: $\mathrm{K}_{2} \mathrm{O}$ ratio of 1 (under the condition of $150 \mathrm{~kg}-\mathrm{N} \mathrm{ha}{ }^{-1}$ and $150 \mathrm{~kg}-\mathrm{K} \mathrm{ha}^{-1}$ fertilization) exhibited the highest tuber biomass production.

Compared with the control group, $\mathrm{K}$ fertilizer treatment significantly increased the dry tuber weight by 77-151\%, with K200 having the highest dry weight (194 g plant $^{-1}$ ). However, the fresh and dry weights of shoots were not significantly different between different $\mathrm{K}$ application rates. 

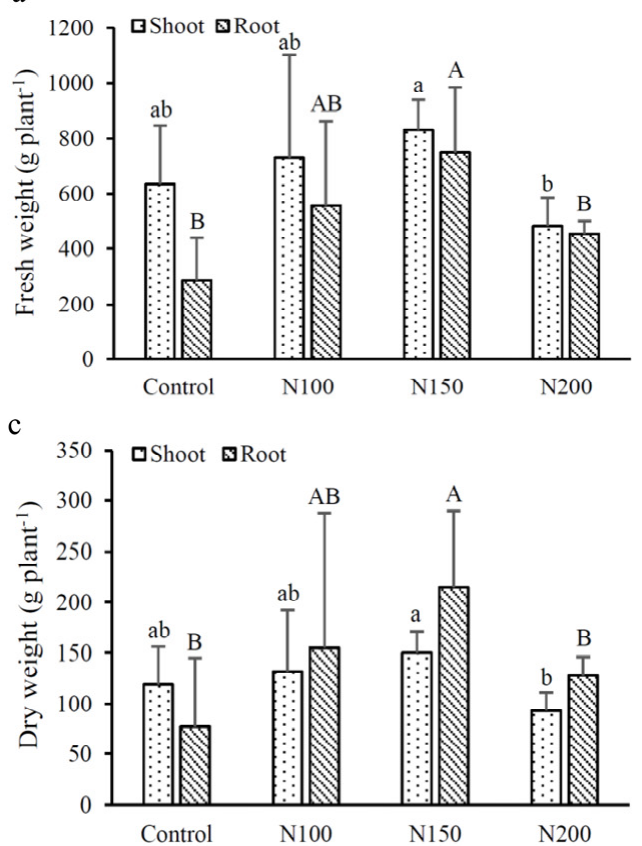

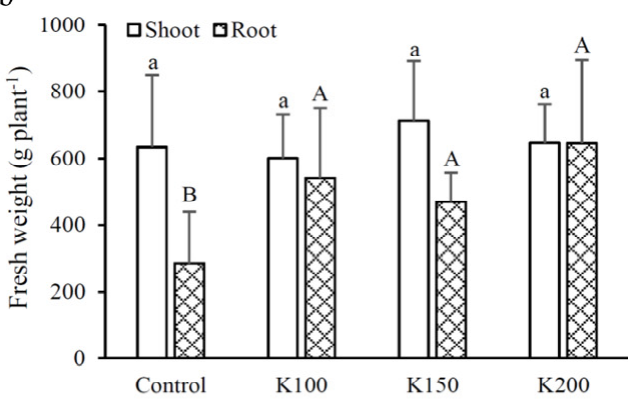

d

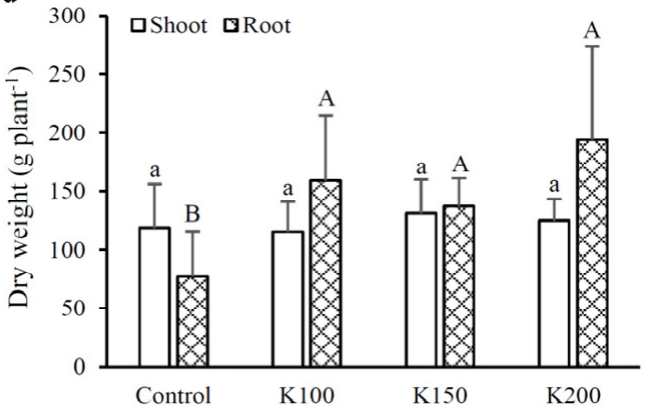

Figure 2. Effects of different fertilizer treatments on the shoot and root biomass of $C$. taiwanianum: (a,b) fresh weight; (c,d) dry weight. Values are mean \pm standard deviation $(n=4)$. The bars with different letters within the same fertilizer treatment (N treatments: Control, N100, N150 and N200; K treatments: Control, K100, K150 and K200) of shoots (lowercase letters) and roots (uppercase letters) are significantly different ( $p<0.05$, LSD tests).

\subsection{Nutrient Uptake in Plant Parts}

The results showed that the shoot and tuber $\mathrm{N}$ contents increased with increasing $\mathrm{K}$ application rates, whereas the $\mathrm{N}, \mathrm{P}$ and $\mathrm{K}$ contents in shoots and tubers were significantly reduced after excessive N application (N200) (Figure 3). The tubers of K200 showed a significantly higher total N, P and K contents than the control group. However, the effects of different $\mathrm{K}$ application rates on total $\mathrm{N}, \mathrm{P}$ and $\mathrm{K}$ contents in shoots were not obvious, while their contents in the tubers appeared to increase significantly with the increasing $\mathrm{K}$ fertilization.

\subsection{Contents of Total Phenols, Total Flavanoids and Polyphenolic Compounds}

The results showed that, with the exception of N200, the total phenolic content in shoots ranged from 5.7 to $6.5 \mathrm{~g} \mathrm{GAE} \mathrm{kg}^{-1}$, and its difference among $\mathrm{N}$ or $\mathrm{K}$ treatments was not statistically significant (Figure 4a). Similarly, the effects of different $\mathrm{N}$ fertilization rates on the total phenolic content in tubers were also not statistically significant, ranging from 4.6 to $5.0 \mathrm{~g} \mathrm{GAE} \mathrm{kg}^{-1}$ (Figure 4c). However, a trend of increasing total phenolic contents was noted with increasing $\mathrm{K}$ fertilization rates.

The total flavonoid contents in the shoots of $\mathrm{N}$ - and $\mathrm{K}$-treated groups varied from 23.5 to $27.8 \mathrm{~g} \mathrm{QUE} \mathrm{kg}^{-1}$ (Figure $4 \mathrm{~b}$ ), and no significant difference was noted among treatments. Similarly, the effects of different $\mathrm{N}$ and $\mathrm{K}$ fertilization rates on total flavonoid content in tubers were also not statistically significant, ranging from 2.5 to $4.3 \mathrm{~g} \mathrm{QUE} \mathrm{kg}^{-1}$ (Figure 4d).

Table 1 shows that the shoots mainly contained six polyphenolic compounds: gallic acid, catechin, chlorogenic acid, epicatechin, ferulic acid and cinnamic acid. With the exception of cinnamic acid in $\mathrm{K}$ treatments, the difference in the contents of these polyphenolic compounds among treatments were not statistically significant. Interestingly, similar polyphenolic compounds were also detected in tubers, with the exception of one compound cinnamic acid that was only present in shoots, while vanillic acid was found in tubers 
but not in shoots. The contents of these polyphenolic compounds in tubers were also not significantly different among $\mathrm{N}$ or $\mathrm{K}$ treatments.
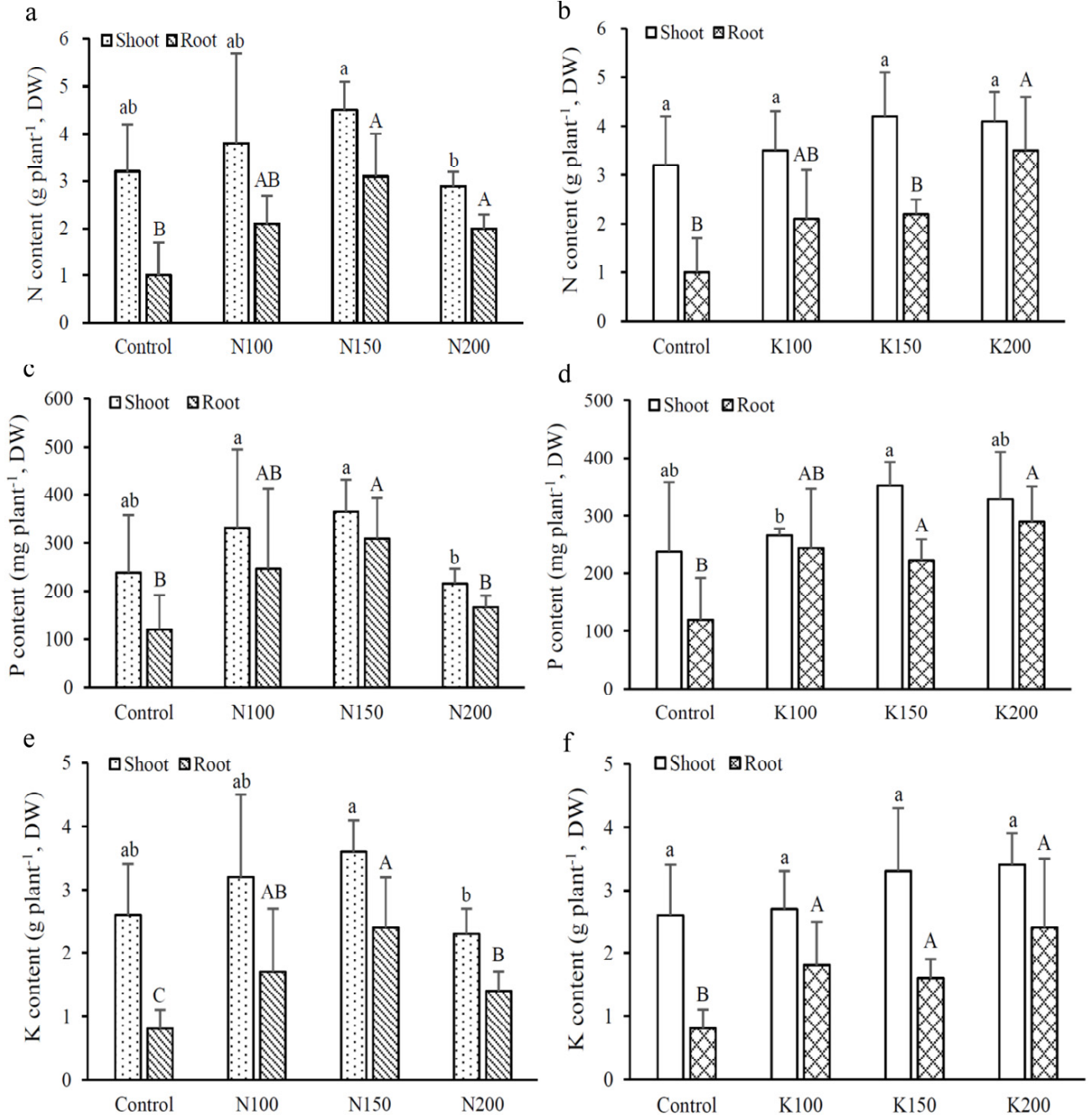

Figure 3. Effects of different fertilizer treatments on total nitrogen, total phosphorus and total potassium contents in shoots and roots of $C$. taiwanianum: $(\mathbf{a}, \mathbf{b})$ total nitrogen contents; $(\mathbf{c}, \mathbf{d})$ total phosphorus contents; $(\mathbf{e}, \mathbf{f})$ total potassium contents. Values are mean \pm standard deviation $(n=4)$. The bars with different letters within the same fertilizer treatment ( $\mathrm{N}$ treatments: Control, N100, N150 and N200; K treatments: Control, K100, K150 and K200) of shoots (lowercase letters) and roots (uppercase letters) are significantly different ( $p<0.05, \mathrm{LSD}$ tests). 

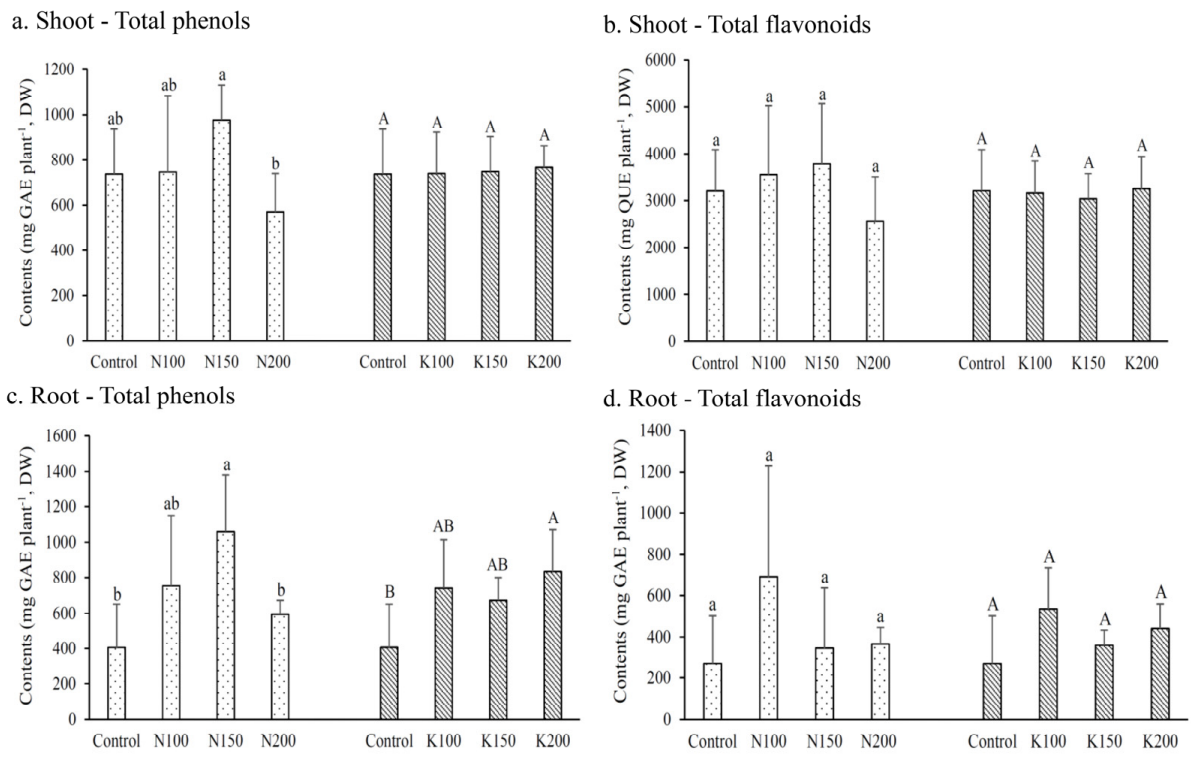

Figure 4. Effects of different fertilizer treatments on the contents of total phenol and total flavonoid contents in the field cultivated C. taiwanianum. Values are mean \pm standard deviation $(n=4)$. The bars with different letters within the same fertilizer treatment (N treatments: Control, N100, N150 and N200; K treatments: Control, K100, K150 and K200) are significantly different ( $p<0.05$, LSD tests).

Table 1. Effects of different fertilization treatments on concentrations of polyphenolic compounds in shoots and roots of field-cultivated C. taiwanianum.

\begin{tabular}{|c|c|c|c|c|c|c|}
\hline \multicolumn{7}{|l|}{ Shoots } \\
\hline & \multicolumn{6}{|c|}{ Concentrations (mg kg $\left.{ }^{-1} \mathrm{DW}\right)$} \\
\hline & Gallic acid & Catechin & Chlorogenic acid & Epicatechin & Ferulic acid & Cinnamic acid \\
\hline \multicolumn{7}{|c|}{ Nitrogen fertilization } \\
\hline Control & $518 \pm 63 a$ & $551 \pm 233 a$ & $335 \pm 73 a$ & $495 \pm 100 \mathrm{a}$ & $383 \pm 271 \mathrm{a}$ & $974 \pm 513 a$ \\
\hline N100 & $523 \pm 92 a$ & $464 \pm 209 a$ & $357 \pm 77 a$ & $538 \pm 170 \mathrm{a}$ & $252 \pm 123 \mathrm{a}$ & $980 \pm 478 \mathrm{a}$ \\
\hline N150 & $438 \pm 185 a$ & $343 \pm 74 a$ & $285 \pm 117 \mathrm{a}$ & $467 \pm 257 \mathrm{a}$ & $299 \pm 125 \mathrm{a}$ & $991 \pm 203 a$ \\
\hline N200 & $424 \pm 228 \mathrm{a}$ & $340 \pm 191 \mathrm{a}$ & $294 \pm 117 a$ & $531 \pm 148 \mathrm{a}$ & $272 \pm 153 \mathrm{a}$ & $1157 \pm 139 \mathrm{a}$ \\
\hline \multicolumn{7}{|c|}{ Potassium fertilization } \\
\hline Control & $518 \pm 63 a$ & $551 \pm 233 a$ & $335 \pm 73 a$ & $495 \pm 100 \mathrm{a}$ & $383 \pm 271 \mathrm{a}$ & $974 \pm 513 b c$ \\
\hline K100 & $416 \pm 93 a$ & $363 \pm 82 a$ & $319 \pm 87 a$ & $538 \pm 185 a$ & $414 \pm 161 \mathrm{a}$ & $1427 \pm 167 \mathrm{a}$ \\
\hline K150 & $461 \pm 91 \mathrm{a}$ & $456 \pm 128 \mathrm{a}$ & $281 \pm 44 \mathrm{a}$ & $425 \pm 125 a$ & $186 \pm 51 \mathrm{a}$ & $597 \pm 133 c$ \\
\hline K200 & $523 \pm 207 a$ & $493 \pm 120 \mathrm{a}$ & $347 \pm 36 \mathrm{a}$ & $504 \pm 92 \mathrm{a}$ & $382 \pm 149 \mathrm{a}$ & $1091 \pm 115 \mathrm{ab}$ \\
\hline \multicolumn{7}{|l|}{ Roots } \\
\hline & \multicolumn{6}{|c|}{ Concentrations $\left(\mathrm{mg} \mathrm{kg}^{-1} \mathrm{DW}\right)$} \\
\hline & Gallic acid & Catechin & Chlorogenic acid & Vanillic acid & Epicatechin & Ferulic acid \\
\hline \multicolumn{7}{|c|}{ Nitrogen fertilization } \\
\hline Control & $100 \pm 43 a$ & $652 \pm 293 a$ & $74 \pm 4 \mathrm{a}$ & $86 \pm 44 a$ & $2550 \pm 741 \mathrm{a}$ & $608 \pm 117 a$ \\
\hline N100 & $106 \pm 16 \mathrm{a}$ & $712 \pm 268 \mathrm{a}$ & $71 \pm 19 a$ & $116 \pm 32 a$ & $2488 \pm 454 \mathrm{a}$ & $842 \pm 388 a$ \\
\hline N150 & $68 \pm 34 \mathrm{a}$ & $682 \pm 230 a$ & $80 \pm 28 \mathrm{a}$ & $133 \pm 62 \mathrm{a}$ & $2521 \pm 738 a$ & $719 \pm 365 a$ \\
\hline N200 & $110 \pm 9 \mathrm{a}$ & $631 \pm 244 \mathrm{a}$ & $71 \pm 13$ a & $135 \pm 45 \mathrm{a}$ & $1844 \pm 328 \mathrm{a}$ & $634 \pm 292 \mathrm{a}$ \\
\hline \multicolumn{7}{|c|}{ Potassium fertilization } \\
\hline Control & $100 \pm 43 a$ & $652 \pm 293 a$ & $74 \pm 4 \mathrm{a}$ & $86 \pm 44 a$ & $2550 \pm 741 \mathrm{a}$ & $608 \pm 117 a$ \\
\hline K100 & $95 \pm 39 a$ & $467 \pm 110 \mathrm{a}$ & $61 \pm 4 \mathrm{a}$ & $75 \pm 10 \mathrm{a}$ & $1802 \pm 113 \mathrm{a}$ & $494 \pm 82 \mathrm{a}$ \\
\hline K150 & $125 \pm 13 a$ & $826 \pm 291 a$ & $63 \pm 6 a$ & $101 \pm 10 \mathrm{a}$ & $2501 \pm 404 \mathrm{a}$ & $667 \pm 194 \mathrm{a}$ \\
\hline K200 & $87 \pm 55 \mathrm{a}$ & $491 \pm 267 \mathrm{a}$ & $61 \pm 7 \mathrm{a}$ & $79 \pm 18 \mathrm{a}$ & $1766 \pm 521 \mathrm{a}$ & $749 \pm 413 \mathrm{a}$ \\
\hline
\end{tabular}

Values are mean \pm standard deviation $(n=4)$. Averages followed by the different letters in the same column of the same fertilizer treatment indicate significant difference between treatments $(p<0.05$, LSD multiple range tests). 


\subsection{Cynandione A Content}

The results showed that cynandione A was not detected in shoots (Figure 5b), and its content in tubers ranged from 1.0 to $1.3 \mathrm{~g} \mathrm{~kg}^{-1}$ and from 0.9 to $1.3 \mathrm{~g} \mathrm{~kg}^{-1}$ in N and $\mathrm{K}$ treatments, respectively (Figure $5 \mathrm{c}, \mathrm{d}$ ). Among the $\mathrm{N}$ treatments, N150 had the highest cynandione A content, whereas excess N fertilization (N200) appeared to decrease its content in tubers. An increasing trend of tuber cynandione A content was noted with increasing $\mathrm{K}$ fertilization rates, and its content in K200 was the highest.
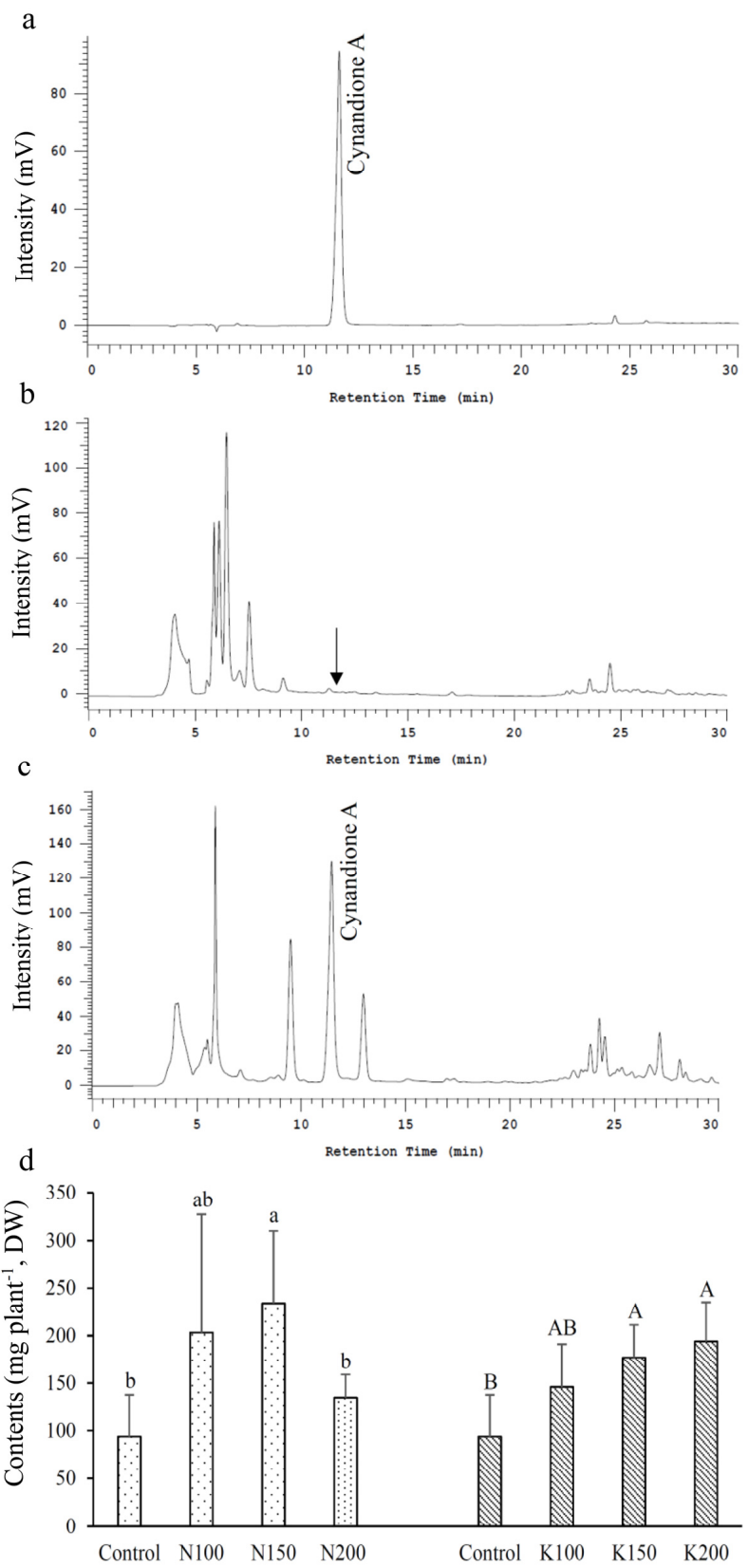

Figure 5. Chromatograms and contents of cynandione A in C. taiwanianum shoots and roots: (a) standard, (b) shoot, (c) roots, (d) cynandione A content in roots of $C$. taiwanianum. Values are mean \pm standard deviation $(n=4)$. The bars with different letters within the same fertilizer treatment (N treatments: Control, N100, N150 and N200; K treatments: Control, K100, K150 and K200) are significantly different $(p<0.05$, LSD tests). 


\section{Discussion}

Fertilization and soil chemical properties play an important role in medicinal plant production; however, the excess fertilization of either $\mathrm{N}, \mathrm{P}$ or K nutrients may affect the quality of plant materials. In this study, the soil $\mathrm{pH}$ taken after $\mathrm{C}$. taizanianum cultivation decreased significantly; its decrease could be due the use of urea, and the soil could be acidified after the nitrification of urea $\mathrm{N}$ [37]. The other reason for the cause of soil acidification could be attributed to the application of potassium sulfate, which may result in the exchange of soil-adsorbed hydrogen ions by potassium. The increasing soil EC values in both $\mathrm{N}$ and $\mathrm{K}$ treatments indicate that fertilization may contribute to the increasing salt content in the soil [38], while the reduction in EC values in the control group after the experiments could be due to the absorption of soil nutrients by $C$. taiwanianum or the leaching of soil nutrients due to irrigation [39].

Before the experiment, the soil total $\mathrm{N}$ contents were around 1.7 and $1.9 \mathrm{~g} \mathrm{~kg}^{-1}$, which were within the range of the total $\mathrm{N}$ content in the general farmland of Taiwan [40]. Without application of any fertilizer in the control plot, the total $\mathrm{N}$ decreased significantly after C. taiwanianum cultivation, indicating that the mineralization of soil $\mathrm{N}$ is significant when compared to the fertilized plots. This is because the only soil $\mathrm{N}$ sources that were available to plants in the control group are from the microbial decomposition of organic matter or plant residues.

The fertilizer-treated groups demonstrated significantly higher contents of extractable $\mathrm{P}$ and $\mathrm{K}$ than the control group. It was surprising to note that the extractable P content in the soil of the control group after C. taiwanianum cultivation was higher than before the experiment. In the case of P-treated groups, the increase in soil extractable P contents after the experiment indicates that the supply of $P$ fertilizer in the field is greater than the supply that can be absorbed by the $C$. taiwanianum plant. Moreover, increasing $\mathrm{K}$ fertilization rates also showed an increase in soil-extractable $\mathrm{P}$ content, which might be a result of the acidification of soil after the application of potassium sulfate and result in the dissolving of the soil-unavailable P.

Studies showed that applications of $\mathrm{K}$ fertilizer can increase the root yield and dry weight of potato [41], sweet potato [42] and yam [43]. In addition, a species from Cynanchum genus (i.e., $C$. bungei) was also reported to have the highest $\mathrm{K}$ absorption during growth [44]; these observations suggest that $\mathrm{K}$ plays an important role in the growth of tuberous root plants. In this study, the extractable $\mathrm{K}$ content in the control group was significantly lower than the fertilizer-treated groups at the end of the experiment, suggesting that the application of $\mathrm{K}$ fertilizer can supplement the available $\mathrm{K}$ in the soil, and match the specific demand of the K nutrients required for growth, as shown by an increasing effect on C. taiwanianum tuber production in the K-treated group.

There was very little difference in soil organic matter content among different $\mathrm{N}$ or $\mathrm{K}$ application rates or between before and after the experiments. As the fertilizers used in this experiment were chemical fertilizers, they cannot supplement the soil organic matter, hence plant residues, such as leaves and weeds dropped during the experimental period, could be the only source of soil organic matter.

In general, the application of appropriate amounts of fertilizer is beneficial to the growth of crops, and applications of $\mathrm{N}$ and $\mathrm{K}$ fertilizers are shown to increase the yield of tuberous crops such as sweet potato and yam [42,43]. Potassium fertilizer has a significant effect on the yield of tuberous root plants because it promotes the expansion of roots [45]. Studies showed that, when the levels of $\mathrm{N}$ fertilization exceeded the appropriate amount, the yield of tubers reduced, such as in potato [46], sweet potato [47] and yam [43], which was consistent with the present finding, where N200 treatment reduced the yield of C. taiwanianum tubers.

It was reported that low $\mathrm{N}$ fertilization rates increased $\mathrm{P}$ uptake by plants, but applying excessive amounts of $\mathrm{N}$ fertilizer decreased $\mathrm{P}$ absorption efficiency of plants, such as in satsumas [48] and Arabidopsis thaliana [49]. The increase in P uptake after low $\mathrm{N}$ application could be attributed to the acidification of the rhizosphere [50] or the effects of mobilizing 
soil P or increasing P uptake efficiency by roots [51], whereas the limitation of P uptake after high $\mathrm{N}$ application could be caused by the competitive inhibition of phosphate absorption (i.e., phosphate ions) by the enhancement of nitrate (i.e., nitrate ions) transport under high-nitrogen conditions [48].

Studies showed that, under sufficient $\mathrm{K}$ fertilization, $\mathrm{K}$ ions can significantly promote the absorption and utilization of $\mathrm{N}$ and $\mathrm{P}$ by crops [48]. In this study, the tubers of K200 showed significantly higher total N, P and K contents than the control group. However, the effects of different $\mathrm{K}$ application rates on total N, P and $\mathrm{K}$ contents in shoots were not clear, while their contents in the tubers appear to increase significantly with increasing $\mathrm{K}$ fertilization.

Among the absorption of N, P and K, C. taiwanianum showed high absorptions of N and $\mathrm{K}$ during the growing period. Consistent with our preliminary studies, $\mathrm{N}$ and $\mathrm{K}$ nutrients influenced the growth of $C$. taiwanianum tubers; this finding is similar to the observations reported on other tuberous crops such as yam, taro and C. bungei cultivation [43,50,52].

Phenols and flavonoids are important secondary metabolites in plants, and are associated with plant resistance to environmental stress for sustaining life [53]. The application of appropriate amounts of $\mathrm{N}$ and $\mathrm{K}$ fertilizers was shown to increase the total phenolic and total flavonoid contents in plants [24,54], while applying excessive amounts of $\mathrm{N}$ fertilizer may cause a decrease in key enzyme activity of $\mathrm{N}$ uptake, resulting in the synthetic protein competing with the phenylpropyl alkane for the secondary metabolic reactant phenylalanine $[55,56]$. Consequently, this reduces the amount of secondary metabolite synthesis; this observation could explain the reason for the reduced total phenolic contents in shoots and tubers of the N200 treatment.

Polyphenolic compounds are ubiquitous in plants and were shown to have good pharmacological effects, including antioxidant and antibacterial effects, inhibiting lipid peroxidation and preventing cardiovascular disease [57]. In this study, both shoots and tubers contained relatively similar detectable amounts of polyphenolic compounds (i.e., gallic acid, catechin, chlorogenic acid, epicatechin and ferulic acid); with the exception of one compound cinnamic acid that was only present in the shoots, while vanillic acid was found in the tubers but not in the shoots. Although the shoots of $C$. taiwanianum were reported to contain caffeic acid and quercetin [58], they were not detected in this study; this is probably due to the differences in the agricultural practices and environmental conditions.

Cynandione $\mathrm{A}$ is the main bioactive compound of $\mathrm{C}$. taiwanianum. It is used as an important marker for the medicinal products of various Cynanchum species, including materials used in the traditional Chinese medicine, namely C. atratum, C. stauntonii and C. Auriculatum; and in Korean herbal medicines, C. wilfordii $[12,13,59]$. This study demonstrates that cynandione A was only present in the tubers but not in the shoots of C. taiwanianum, and its exact mechanism(s) and site of biosynthesis remains unknown; it is possible that the different secondary metabolites are accumulated in different plant parts [60] Although the function of cynandione $\mathrm{A}$ in the $\mathrm{C}$. taiwanianum plant remains unknown, the present results suggest that $\mathrm{K}$ fertilization favors the biosynthesis of cynandione $\mathrm{A}$.

\section{Conclusions}

This study demonstrates that appropriate amounts of $\mathrm{N}$ and $\mathrm{K}$ fertilization can increase the shoot and tuber dry weight of $C$. taiwanianum, and $\mathrm{K}$ is an important nutrient for the development of its tubers. High $\mathrm{N}$ fertilization resulted in lower total phenolic and total flavonoid contents in both shoots and tubers, whereas the effects of K fertilization rates on their contents were minimal. Potassium, but not $\mathrm{N}$ fertilizer application, favors cynandione A biosynthesis. When considering the better tuber yield and its contents of functional components, it was found that $\mathrm{N}$ fertilizer greater than $150 \mathrm{~kg} \mathrm{~N} \mathrm{ha}^{-1}$ showed no improvement in the $C$. taiwanianum tuber quality. However, optimal biomass and the quality of tubers appears to be under the condition of N150 and K150 fertilization treatment. The results of these field experiments also indicate that the important secondary metabolite 
cynandione A only exists in the tubers of C. taiwanianum, and its mechanism of biosynthesis still needs further investigation.

Supplementary Materials: The following supporting information can be downloaded at: https: / / www.mdpi.com/article/10.3390/agronomy12010180/s1, Figure S1: Average monthly field temperature during C. taiwanianum cultivation (From October 2016 to March 2017), Figure S2: Average monthly field precipitation during C. taiwanianum cultivation (From October 2016 to March 2017), Table S1: Design of different fertilizer treatments in field experiments.

Author Contributions: H.-M.T. conducted the experiment, analyzed the data and prepared the original draft. T.-M.L. was responsible for the isolation and purification of cynandione A. L.-T.N. carried out the conceptualization, supervision and revision of the manuscript. All authors have read and agreed to the published version of the manuscript.

Funding: This research was funded by the Ministry of Science and Technology of Taiwan, grant number MOST 103-2313-B-002-022.

Conflicts of Interest: The authors declare no conflict of interest.

\section{References}

1. Lin, C.C.; Yen, M.H.; Wu, Y.W.; Xu, G.J. Histological study on crude drugs Pai-wei, Pai-chein and indigenous species of Cynanchum in Taiwan. Am. J. Chin. Med. 1995, 23, 305-312. [CrossRef] [PubMed]

2. Lee, H.I. Studies of Antioxidant, Antimicrobial and Anti-Inflammatory Activities of Cynanchum taiwanianum Yamazaki. Ph.D. Thesis, Department of Food Science, National Pingtung University of Science and Technology, Pingtung, Taiwan, 2012; 173p.

3. Huang, P.L.; Lu, C.M.; Yen, M.H.; Wu, R.R.; Lin, C.N. Acetophenones from Cynanchum taiwanianum. Phytochemistry 1996, 41, 293-295. [CrossRef]

4. Huang, P.L.; Won, S.J.; Day, S.H.; Lin, C.N. A cytotoxic acetophenone with a novel skeleton, isolated from Cynanchum taiwanianum. Helv. Chim. Acta 1999, 82, 1716-1720. [CrossRef]

5. $\quad$ Lin, C.N.; Huang, P.L.; Wang, J.J.; Day, S.H.; Lin, H.C.; Wang, J.P.; Ko, Y.L.; Teng, C.M. Stereochemistry and biological activities of constituents from Cynanchum taiwanianum. Biochim. Biophys. Acta 1998, 1380, 115-122. [CrossRef]

6. Lin, C.N.; Huang, P.L.; Lu, C.M.; Yen, M.H.; Wu, R.R. Revised structure for five acetophenones from Cynanchum taiwanianum. Phytochemistry 1997, 44, 1359-1363.

7. Lin, Y.L.; Lin, T.C.; Kuo, Y.H. Two acetophenone glucosides, cynanonesides A and B, from Cynanchum taiwanianum and revision of the structure for cynandione A. J. Nat. Prod. 1997, 60, 368-370. [CrossRef]

8. Lin, Y.L.; Wu, Y.M.; Kuo, Y.H. Revised structures for four acetophenones from Cynanchum taiwanianum. Phytochemistry 1997, 45, 1057-1061. [CrossRef]

9. Lin, Y.L.; Lin, T.C.; Kuo, Y.H. Five new pregnane glycosides from Cynanchum taiwanianum. J. Nat. Prod. 1995, 58, 1167-1173. [CrossRef]

10. Lee, H.I.; Guo, J.H.; Wu, C.C.; Ti, M.C.; Lan, K.P.; Hu, C.Y.; Lo, C.Y.; Yang, C.C.; Lin, Y.F.; Wang, T.C. Anti-inflammatory effects of Cynanchum taiwanianum rhizome aqueous extract in IL-1 $\beta$-induced NRK-52E cells. Pharm. Biol. 2011, 49, 437-444. [CrossRef]

11. Yue, R.; Yuan, X.; Liu, X.; Zhang, J.; Jiang, P.; He, C.; Shan, L.; Yu, Y.; Zhang, W. Cynandione A mitigates ischemic injuries in rats with cerebral ischemia. J. Neurochem. 2012, 121, 451-464. [CrossRef]

12. Yang, S.B.; Lee, S.M.; Park, J.H.; Lee, T.H.; Baek, N.I.; Park, H.J.; Lee, H.; Kim, J. Cynandione A from Cynanchum wilfordii attenuates the production of inflammatory mediators in LPS-induced BV-2 microglial cells via NF- $\mathrm{kB}$ inactivation. Biol. Pharm. Bull. 2014, 37, 1390-1396. [CrossRef]

13. Lee, M.K.; Yeo, H.; Kim, J.; Markelonis, G.J.; Oh, T.H.; Kim, Y.C. Cynandione A from Cynanchum wilfordii protects cultured cortical neurons from toxicity induced by $\mathrm{H}_{2} \mathrm{O}_{2}$, L-glutamate, and kainate. J. Neurosci. Res. 2000, 59, 259-264. [CrossRef]

14. Jiang, H.W.; Gu, S.S.; Cao, L.; Jiang, S.S.; Lin, J.; Chen, Y.; Wang, L.; Jiao, H.; Li, J.Y.; Zhao, W.M.; et al. Potential hypoglycemic effect of acetophenones from the root bark of Cynanchum wilfordii. Nat. Prod. Res. 2019, 33, 2314-2321. [CrossRef] [PubMed]

15. Han, Q.Q.; Yin, M.; Wang, Z.Y.; Liu, H.; Ao, J.P.; Wang, Y.X. Cynandione A alleviates neuropathic pain through $\alpha 7-n A C h R-$ dependent IL-10/ $\beta$-endorphin signaling complexes. Front. Pharmacol. 2021, 11, 614450. [CrossRef] [PubMed]

16. Chung, R.S.; Chen, C.C.; Ng, L.T. Nitrogen fertilization affects the growth performance, betaine and polysaccharide concentrations of Lycium barbarum. Ind. Crops Prod. 2010, 32, 650-655. [CrossRef]

17. Sugiyama, M.; Takahashi, M.; Katsube, T.; Koyama, A.; Itamura, H. Effects of applied nitrogen amounts on the functional components of Mulberry (Morus alba L.) leaves. J. Agric. Food Chem. 2016, 64, 6923-6929. [CrossRef] [PubMed]

18. Westermann, D.T.; James, D.W.; Tindall, T.A.; Hurst, R.L. Nitrogen and potassium fertilization of potatoes: Sugars and starch. Am. Potato J. 1994, 71, 433-453. [CrossRef]

19. Koch, M.; Naumann, M.; Pawelzik, E.; Gransee, A.; Thiel, H. The importance of nutrient management for potato production part I: Plant nutrition and yield. Potato Res. 2020, 63, 97-119. [CrossRef] 
20. Epstein, E.; Bloom, A.J. Mineral Nutrition of Plants: Principles and Perspectives, 2nd ed.; Sinauer Associates Inc.: Sunderland, MA, USA, 2005; p. 400.

21. Kováčik, J.; Klejdus, B.; Bačkor, M.; Repčák, M. Phenylalanine ammonia-lyase activity and phenolic compounds accumulation in nitrogen-deficient Matricaria chamomilla leaf rosettes. Plant Sci. 2007, 172, 393-399. [CrossRef]

22. Taiz, L.; Zeiger, E.; Møller, I.M.; Murphy, A. Plant Physiology and Development; Sinauer Associates, Inc.: Sunderland, MA, USA, 2015; 700p.

23. Nguyen, P.M.; Kwee, E.M.; Niemeyer, E.D. Potassium rate alters the antioxidant capacity and phenolic concentration of basil (Ocimum basilicum L.) leaves. Food Chem. 2010, 123, 1235-1241. [CrossRef]

24. Redovniković, I.R.; Bogović, M.; Belko, D.; Delonga, K.; Fabek, S.; Novak, B.; Toth, N. Influence of potassium fertilization on the levels of phenolic compounds in sweet potato (Ipomoea batatas L.) leaves. J. Hortic. Sci. Biotechnol. 2012, 87, 47-51. [CrossRef]

25. Gremigni, P.; Wong, M.T.F.; Edwards, N.K.; Harris, D.; Hamblin, J. Potassium nutrition effects on seed alkaloid concentrations, yield and mineral content of lupins (Lupinus angustifolius). Plant Soil 2001, 234, 131-142. [CrossRef]

26. Ehsanipour, A.; Razmjoo, J.; Zeinali, H. Effect of nitrogen rates on yield and quality of fennel (Foeniculum vulgare Mill.) accessions. Ind. Crops Prod. 2012, 35, 121-125. [CrossRef]

27. Heimler, D.; Romani, A.; Ieri, F. Plant polyphenol content, soil fertilization and agricultural management: A review. Eur. Food Res. Technol. 2017, 243, 1107-1115. [CrossRef]

28. Stumpf, B.; Yan, F.; Honermeier, B. Nitrogen fertilization and maturity influence the phenolic concentration of wheat grain (Triticum aestivum). J. Plant Nutr. Soil Sci. 2015, 178, 118-125. [CrossRef]

29. McLean, E.O. Soil pH and lime requirement. In Methods of Soil Analysis. Part 2. Chemical and Microbiological Properties, 2nd ed.; Page, A.L., Ed.; American Society of Agronomy Inc.: Madison, WI, USA, 1982; pp. 199-224.

30. Rhoades, J.D. Soluble salts. In Methods of Soil Analysis. Part 2. Chemical and Microbiological Properties, 2nd ed.; Page, A.L., Ed.; American Society of Agronomy Inc.: Madison, WI, USA, 1982; pp. 167-178.

31. Murphy, J.; Riley, J.P. A modified single solution method for the determination of phosphate in natural waters. Anal. Chim. Acta 1962, 27, 31-36. [CrossRef]

32. Mehlich, A. Mehlich 3 soil test extractant: A modification of Mehlich 2 extractant. Commun. Soil Sci. Plant Anal. 1984, 15, 1409-1416. [CrossRef]

33. Bremner, J.M.; Mulvaney, C.S. Nitrogen-total methods of soil analysis. In Methods of Soil Analysis. Part 2. Chemical and Microbiological Properties, 2nd ed.; Page, A.L., Ed.; American Society of Agronomy Inc.: Madison, WI, USA, 1982; pp. 595-624.

34. Soon, Y.K.; Abboud, S. A comparison of some methods for soil organic carbon determination. Commun. Soil Sci. Plant Anal. 1991, 22, 943-954. [CrossRef]

35. $\mathrm{Wu}, \mathrm{S} . J . ; \mathrm{Ng}, \mathrm{L} . \mathrm{T}$. Antioxidant and free radical scavenging activities of wild bitter melon (Momordica charantia Linn. var. abbreviata Ser.) in Taiwan. LWT-Food Sci. Technol. 2008, 41, 323-330. [CrossRef]

36. Huang, S.H.; $\mathrm{Ng}$, L.T. Quantification of polyphenolic content and bioactive constituents of some commercial rice varieties in Taiwan. J. Food Compos. Anal. 2012, 26, 122-127. [CrossRef]

37. Cai, Z.; Wang, B.; Xu, M.; Zhang, H.; Zhang, L.; Gao, S. Nitrification and acidification from urea application in red soil (Ferralic Cambisol) after different long-term fertilization treatments. J. Soils Sediments 2014, 14, 1526-1536. [CrossRef]

38. Citak, S.; Sonmez, S. Effects of chemical fertilizer and different organic manures application on soil pH, EC and organic matter content. J. Food Agric. Environ. 2011, 9, 739-741.

39. Machado, R.M.A.; Serralheiro, R.P. Soil salinity: Effect on vegetable crop growth. Management practices to prevent and mitigate soil salinization. Horticulturae 2017, 3, 30. [CrossRef]

40. Lin, Y.R.; Cheng, C.H.; Tseng, T.Y.; Wang, S.L.; Guo, H.Y. Soil properties and organic carbon sequestration in the long-term afforested stands of plain areas. Taiwan J. Agric. Chem. Food Sci. 2011, 49, 260-274.

41. Allison, M.F.; Flower, J.H.; Allen, E.J. Responses of potato (Solanum tuberosum) to potassium fertilizers. J. Agric. Sci. 2001, 136, 407-426. [CrossRef]

42. Pen, W.N.; Hsin, T.W.; Lin, W.H. The effect of plant densities and potassium fertilizations on root tuber size and yield of sweet potato. Bull. Taoyuan Dist. Agric. Res. Ext. Stn. 1994, 17, 1-8.

43. Kung, T.L.; Jiang, J.L.; Hsin, T.W. The effect of nitrogen and potassium fertilizers on agronomic characteristics and tuber yield of Chinese yam (Dioscorea batatas). Bull. Taoyuan Dist. Agric. Res. Ext. Stn. 1999, 36, 1-6.

44. Zhang, F.; Wang, J.H.; Yu, S.L.; Chen, Y.H.; Dong, Q.Y. Accumulation and distribution of nitrogen, phosphorus, and potassium in Cynanchum bungei Decne. and their relationships to dry matter production. Soil Sci. Plant Nutr. 2006, 12, 369-373.

45. Haeder, H.E.; Mengel, K.; Forster, H. The effect of potassium on translocation of photosynthates and yield pattern of potato plants. J. Agric. Food Chem. 1973, 24, 1479-1487. [CrossRef]

46. Porter, G.A.; Sisson, J.A. Response of Russet Burbank and Shepody potatoes to nitrogen fertilizer in two cropping systems. Am. Potato J. 1991, 68, 425-443. [CrossRef]

47. Chen, X.G.; Li, H.M.; Zhang, A.J.; Shi, X.M.; Tang, Z.H.; Wei, M.; Shi, C.Y. Effect of paclobutrazol under different N application rates on photosynthesis and starch accumulation in edible sweet potato. Acta Agron. Sin. 2012, 38, 1728-1733.

48. Li, Z.G.; Zhang, R.H.; Xia, S.J.; Wang, L.; Liu, C.; Zhang, R.Q.; Fan, Z.H.; Chen, F.; Liu, Y. Interactions between N, P and K fertilizers affect the environment and the yield and quality of satsumas. Glob. Ecol. Conserv. 2019, 19, e00663. [CrossRef] 
49. Yan, Z.; Kim, N.; Han, W.; Guo, Y.; Han, T.; Du, E.; Fang, J. Effects of nitrogen and phosphorus supply on growth rate, leaf stoichiometry, and nutrient resorption of Arabidopsis thaliana. Plant Soil 2015, 388, 147-155. [CrossRef]

50. Thomson, C.; Marschner, H.; Römheld, V. Effect of nitrogen fertilizer form on pH of the bulk soil and rhizosphere, and on the growth, phosphorus, and micronutrient uptake of bean. J. Plant Nutr. 1993, 16, 493-506. [CrossRef]

51. Ruan, J.; Zhang, F.; Wong, M.H. Effect of nitrogen form and phosphorus source on the growth, nutrient uptake and rhizosphere soil property of Camellia sinensis L. Plant Soil 2000, 223, 65-73. [CrossRef]

52. Tsai, J.H.; Wu, T.Y. Soil information and fertilization recommendation of taro in paddy field at Miaoli district. Bull. Taoyuan Dist. Agric. Res. Ext. Stn. 2017, 6, 1-14.

53. Wills, R.B.; Bone, K.; Morgan, M. Herbal products: Active constituents, modes of action and quality control. Nutr. Res. Rev. 2000, 13, 47-77. [CrossRef]

54. Amarowicz, R.; Cwalina-Ambroziak, B.; Janiak, M.A.; Bogucka, B. Effect of N fertilization on the content of phenolic compounds in Jerusalem artichoke (Helianthus tuberosus L.) tubers and their antioxidant capacity. Agronomy 2020, 10, 1215. [CrossRef]

55. Jones, C.G.; Hartley, S.E. A protein competition model of phenolic allocation. Oikos 1999, 86, 27-44. [CrossRef]

56. Mittelstraß, K.; Treutter, D.; Pleßl, M.; Heller, W.; Elstner, E.F.; Heiser, I. Modification of primary and secondary metabolism of potato plants by nitrogen application differentially affects resistance to Phytophthora infestans and Alternaria solani. Plant Biol. 2006, 8, 653-661. [CrossRef] [PubMed]

57. Rasouli, H.; Hosein Farzaei, M.; Khodarahmi, R. Polyphenols and their benefits: A review. Int. J. Food Prop. 2017, $20,1700-1741$. [CrossRef]

58. Chen, Z.S.; Lai, J.S.; Kao, Y.H. The constituents of Cynanchum taiwanianum. J. Chin. Chem. Soc. 1991, 38, 393-396. [CrossRef]

59. Li, Y.; Piao, D.; Zhang, H.; Woo, M.H.; Lee, J.H.; Moon, D.C.; Lee, S.H.; Chang, H.W.; Son, J.K. Quality assessment and discrimination of the roots of Cynanchum auriculatum and Cynanchum wilfordii by HPLC-UV analysis. Arch. Pharm. Res. 2013, 36, 335-344. [CrossRef] [PubMed]

60. Wink, M. Physiology of accumulation of secondary metabolites with special reference to alkaloids. In Cell Cultures and Somatic Cell Genetics of Plants; Constabel, F., Vasil, I.K., Eds.; Academic Press: San Diego, CA, USA, 1987; Volume 4, pp. 17-42. 